\title{
The Efforts of the Office of the Religious Affairs of South Palu in Resolving Marriage Conflicts
}

\author{
Ismail Ismail ${ }^{1 *}$,Abidin Abidin ${ }^{2}$, and Lukman Tahir ${ }^{3}$ \\ ${ }^{1}$ Islamic Law Department, Postgraduate, Institut Agama Islam Negeri Palu \\ ${ }^{2}$ Islamic Law Department, Faculty of Syariah, Institut Agama Islam Negeri Palu \\ ${ }^{3}$ Faculty of Islamic Phylosophy, Institut Agama Islam Negeri Palu
}

\begin{abstract}
This study discusses the efforts of the Office of the Religious Affairs (KUA) South Palu District to resolvemarital conflict in the district. This research uses descriptive qualitative approach where different data collection techniques are employed such as observation, interview and documents reviews.Data analysis used applies data reduction, data presentation and data verification while consistently considering its validity. The results of this study indicate that the efforts of the KUA of South Palu District in settling down marriage conflict while disseminating the marriage law No. 1, 1974 to the community.At the time of giving marriage counselling and in other religious events such as regular recitation held at the local mosque the head of the KUA do not forget to provide explanations to the public about the adverse impacts on marital conflicts. He also highlights the importance of maintaining harmonious family. Furthermore, the head of the KUA and his staff continuously do marriage counseling to inculcate the understanding about the importance of maintaining harmony in the household to the people in public especially to prospective brides and bride grooms. The head of the KUA and his staff also provide guidance in regard to rights and obligations of a husband and a wife, parental responsibilities to children. The KUA provide supports, adequate facilities and infrastructure, cooperation with other institutions, availability of regulations that support the implementation of the KUA programs. In addition, a commitment to accountable leadership as a determining factor in the attempts of the KUA to achieve the objectives within which the form of acceleration of the Commitment of the Head of the KUA, Penghulu, or in charge person to be either a guardian of a bride or to hold a marriage, and the role of religious figures in the community are the main goals of the office of the religious affairs.
\end{abstract}

ARTICLE

INFORMATION

\section{Keywords:}

Marriage conflict, Marriage settlement, Government roles, 


\section{INTRODUCTION}

The breakup of a marriage ties occurs due tomany potential marriage disputes. Disputes in a marriage could happen due to marriage ties between a husband and a wife can no longer co-exist.

The continuity of family life should be everyone's hope in their marriage. No one expects to have disputes in their family lives. However, problems may arise in a marriage that could potentially cause disputes and prone to decline ties of marriages. In such a situation, it is strongly expected to have a peace maker (qadhi) helped them solve theirproblemsfor their marriage survival.

If the peace effort is not accepted by both husband and wife, the next peace effort taken to two peacemakers, each consisting of husband and wife's family as referred to in the Qur'an (QS al-Nisaa '[4]: 35), which means:

"And if you are worried about a dispute between the two, then send knowledgeable peacemaker from a male family and a peacemaker from a female family. If both of them (peacemakers) intend to make improvements, surely Allah gave guidance to the husband and wife. Verily, Allah is the All-knowing. "l

This verse emphasizes that when dispute occurs, it is ordered to send a third party (hakam) or a jury from husband's and wife's sides to reconcile them. In this case, the ulamaor scholars of jurisprudence (fiqh)agreed to state that if hakam or a jury (peacemakers on the side of a husband or wife) disagree, their decisions cannot be carried out.However, if hakam from both sides decide to reconcile a husband and a wife again, then the decision must be carried out without asking their agreement. ${ }^{2}$ In the Qur'an there is no verse that explains aboutwhether a couple is or not allowed to divorce when there is a conflict in the household. This is because divorce is hated by Allah, the Most High. Instead, The Almighty Allah rather provides a way out with such mediation process ${ }^{3}$ mentioned in the holy book of Muslim, i.e. Qur'an.

This verse also explains the appointment of hakam or a jury.If anyone knows that there is a fight between husband and wife, while any of you do not know who

\footnotetext{
${ }^{1}$ Kementerian Agama RI, $A l$ qur'andanTerjemahnyaEdisiTransliterasi (Solo: TigaSerangkai, 2013), 84.

${ }^{2}$ Dahlan, Dkk, EnsiklopediHukum Islam (Jakarta: PT IchtiarBaru van Hoeve, 1996), 1750.

${ }^{3}$ Ahmad Musthofa Almaraghiy, Tafsir al maraghiy ( $J$ ilid 5),Terjemahan K Anshori Umar
}

(Semarang, Toha Putra , 1988), 49. 
is guilty and they continue to dispute, this verse shows the ability to raise hakam. ${ }^{4}$

Suggestions, advice, and considerations from parties or institutions that are neutral and have recognized quality, are invaluable input for troubled families as a consideration in making decisions to resolve their problem. Indonesian society shows quite serious attention to this matter by providing solutions recommended by the holy book of Muslims and the tradition of the Beloved Prophet(SAW - may peace and blessings be always upon him - P.B.U.H) to overcome and solve family problems for the sake of a family's longevity.

Marriage counseling institutions both carried out by individuals and groups appear as a real positive response to this phenomenon. Marriage conflicts that potentially cut ties of marriages in this case the relationship of husband and wife, according to AmirSyarifuddinmay occur by 4 possibilities, namely:

1. by the will of Allah Himself through death of a husband or a wife.

2. by the will of a husband

3. bythewife's will

4. by the will of a judge as a third party. ${ }^{5}$

${ }^{4}$ Teungku Muhammad Hasby Ash Ahiddieqy, $A l$ Bayan, TafsirPenjelas Al-Qur'anulKarim, (Semarang: PT. PustakaRizki Putra, 2002), 193.
In line with this, marriage law in Indonesia recognizes several causes of marital conflict that cause divorce. Divorce is done not only by a husband but also by a wife. In religious courts in Indonesia, there are terms and conditions for anyone to divorce. A sue type of divorce is a case where the party who filed for divorce is a wife. While repudiation type of divorce or talak is a divorce case where the party who filed or the party who wanted it is a husband. Both of these types of divorce have bad implications for the life of a family, especially for children who will certainly be victims of the decision. Both parents should consider it carefully if they want to make such decision.

In the family of both parties, sometimes they look for and make various efforts to prevent divorce between their children. These could be advices and persuasive talks to both parties (husband and wife), consultations with their family, or consulting and mediating the case with third parties. This is made to reassure happy andharmony in family lives of a husband and a wife on the basis of the teaching of the Qur'an. In the end, it is the effort to

\footnotetext{
${ }^{5}$ Amir Syarifuddin, HukumPerkawinan Islam di Indonesia: AntaraFiqhMunakahatdanUndangundangPerkawinan, Cet. III (Jakarta:

KencanaPrenada Media Group, 2006), 34.
} 
establishfamily with sense of love, peace, and hope (mawaddahwarahmah). ${ }^{6}$

A harmonious, happy and prosperous family is not only a dream of a husband or a wife or family but also a dream of the country. Family is a small picture of the actual life of a country. If every family becomes happy and prosperous, the country will become prosperous. Harmonious relationships within each family is expected to create harmony between families and communities so as to create national security and stability.

For this reason, the government strives for its citizens to be able to become harmonious, happy and prosperous families by forming an institution called the Office of the Religious Affairs (KUA). The office functions as a guide, counselor, advisor, consultant and mediator for citizens who will establish a family (premarital) or residents who are married and face problems.

\section{LITERATURE REVIEW}

\subsection{Prior Research}

This study is entitled "The Role of Family Counseling in the TampanDistrict of Pekanbaru in its Attempt to Overcome Divorce under the Islamic Law." The case

${ }^{6} I b i d$. shows that a couple canceled their intention to divorce after having advices from the family counseling at the Office of the Religious Affairs (KUA), Tampansubdistrict, Pekanbaru. ${ }^{7}$

In this study, the authors formulated three main problems namely; (1) What is the role of family counseling in preventing and providing guidance to married couples? (2) What are the steps?Do family counseling prevent divorce? (3) and How is the analysis of the Islamic law in regard to the role of family counseling in preventing divorce?

After collecting data of the research, the data were analyzed using qualitative data analysis. In this analysis, the data were classified based on equations. The data were further analyzed and described clearly to obtain a complete picture of the problem to be studied. ${ }^{8}$

The results of the study show that providing family counselling has a significant influence in the attempt to overcome divorce amongst married couples in the sub-district. The influence can be seen from pre-marriage (three or four days before

\footnotetext{
${ }^{7}$ Hasanudin,

TesisPeranKonselingKeluargaKecamatanTampan Kota

PekanbaruDalamMengatasiPerceraianDitinjauMenur utHukum Islam (Riau: UIN Sultan SyarifKasim, 2010), xi.

${ }^{8}$ Ibid
} 
the marriage contract) and post-marriage (when a husband and a wife experience family conflict). When the data were presented, the rate resulted in its attempt to overcome divorce in the sub-district stood at $75 \%$. In comparison, the numbers of marriages is far greater than the divorce rate. Within three months, there were 180 married couples, while within that same period, there were only 7 married couples were found to have divorced with a percentage of $4 \%{ }^{9}$

Another study on this matter is the study entitled "Communication of InterCultural Conflict Solutions in JavaneseChinese Marriage Families in Surakarta". This study employs interpretive approach where respondents are the subjects of research.Methodologically, the study seeks to understand and describe communication behaviors of the cultural diverse families. Supporting interpretive approaches, phenomenological traditions are used to look into one's experience, including the experience of the researcher with others. Thus, intercultural communication theory can be more easily understood. ${ }^{10}$

\footnotetext{
${ }^{9} /$ bid

${ }^{10}$ RulliyantiPuspowardhani,

TesiskomunikasiterhadasolusikonflikAntarbudayadal amKeluargaKawinCampurJawa-Cina di Surakarta (Surakarta: UniversitasSebelasMaret, 2008), ix.
}

The subjects of the research is mixed marriages with various backgrounds. This isintended to compare the experience of each individual. The findings suggest that it would contribute to the study about intercultural communication.

The results of the research are: Facing the issue of intercultural communication, in the context of mixed marriages, stereotypes can affect judgments of extended families of someone who will be made as a life companion. The kinship in the ethnic Chinese is strong and thereforefamilies' opinion is always taken into consideration for making decisions. Consequently, an extraordinary commitment by a married couple is required, so that all forms of misunderstanding can be more easily resolved. This includes when each party makes adjustments to terms and conditions of both parties so that marriage can occur. This example show that there are similarities between Javanese and Chinese in regard to terms and conditions for marriage. ${ }^{11}$

The second problem is the personal or individual background of the intermarried agents. The majority of couples who decide to have a marriage of this type must have an open mindset to the culture of their partners within which beliefs, values and norms are 
to be carefully taken into account of both parties. If the two parties do not have an open mindset, there will be coercion of the will to practice one's belief, values and norms held by his or her partners.

The research entitled "BirrulWalidain, as a Background for Addressing Problems in Encountering Family Conflict in Converts (Phenomenology Studies)" is another study which is interesting to better understand the topic of the current study. Conversion to a religion is not an easy job. This is because a decision to convert to a particular religion will often be rejected by ones' family. ${ }^{12}$

This study aims to understand howcoping strategy is used to deal with families in individuals who decide to convert toareligion. ${ }^{13}$ The number of subjects in this study were 10 people consisting of 4 men and 6 women. Data collection is obtained from interviews. Data analysis of the study employs qualitative

12

Rizqa Hazmar, TesisBirrulWalidain, SebagaiLatarBelakangPengatasanMasalahDalamMen ghadapiKonflikKeluargaPadaMualaf(StudiFenomeno logi) (Riau: UIN Sultan SyarifKasim, 2014), x.

${ }^{13}$ Copinginisecarabahasamempunyaimaknamenanggg gulangi,

menerimamenguasaisegalasesuatuyangberangkutande ngandirikitasendiri.

Untukmengendalikanemosibisadilakukandenganbany akcara, diantaranyadengan model penyesuaian, pengalihandan coping. method while adopting phenomenological approach. $^{14}$

Based on the results of the study, the subject realizes that every religion teaches goodness and kindness in terms of maintaining good relationships with ones' parents. In Islam, the virtues offered by a child to his parents are called

\section{BirrulWalidain.}

In order to do good continuously and remains devoted to parents create positive expectations thatissolving problems by wisdom.In addition, seeking emotional support from the closest people, submit and hide their new religious identity and activities are other effective ways to solve problems in this matter.

Second, making efforts to approach family or deliberately seeking social support from ones'closest people, trying to persuade his or her family, and keeping a good try to establish communication with ones' family could be good ways to solve the problems in this matter.

Third, by avoiding problems that is leaving home and living apart from extended familieswhile maintaining friendship with them could be a good solution for this matter.

\footnotetext{
${ }^{14}$ Ibid.
} 
The difference between the researchers' thesis and Hasanudin's thesis is that the issues discussed in the thesis of Hasanuddin are more specific to the role of the KUA in its attempt to overcome divorce through family counseling according to the Islamic law. While this thesis emphasizes the role of the KUA in ensuring a sakinahfamily or a family which maintains loves, hope, and peace in the household.However, both of these theses use field study.

In the thesis of RulliyantiPuspowardhani the difference is that thesis strongly emphasizes communication problem of inter-cultural conflict solutions in Javanese-Chinese Marriage Families in Surakarta. This thesis is different from the current study in terms of the topic of discussionandthesetting of the study. However, both of the studies use field study. So does the study of Rizqa in regards to BirrulWaalidain. This study is totally different from the current study. Despite the case, the study of Rizqa and the current study both look into family affairs.

\subsection{The Concept of Family According to} Teaching of Islam
Family is a basic unit consisting of husband, wife and children. ${ }^{15}$ Family in the view of Islam has invaluable values. Islam pays great attention to family life by laying down wise rules in order to maintain family life from disharmony and destruction. Why does family have much attention in Islam? It is undeniable that family is the first brick to build a palace which is so called Muslim community.It is a madrasa of faith that is expected to print generations of Muslims who are able to raise the Deen of Allah on earth.

If this foundation is strong, morals of the members will be strong. Thus, the community will be strong and in the end security will be achieved. On the other hand, if the family ties are broken up and its damage poisons the members, the impact will be seen in the community which could be shock hits and fragility of its members. This chaos eventually will affect security of all mankind. ${ }^{16}$

In every family or a group or a group of people, where two or more individuals co-exist must have a leader or someone who

\footnotetext{
${ }^{15}$ Mulyono M. Idris, HukumPerkawinan Islam (Jakarta: BumiAksara, 1994), 65.

${ }^{16}$ Abdul Qadir Muhammad, ProbelamatikaKeluarga(Bandung: PT Aditya Bakti, 2012), 130.
} 
has the authority to enforce rules and regulations. ${ }^{17}$

Likewise, the so-called family is consists of a husband and a wife and children. A family also needs a leader whose job is to guide and drive the family members according to the teaching of Islam. As the head of the falmily, there are terms and conditions to fulfill in order to establishsakinah, mawaddahwarahmahfamilywhich means a family bound to sense of loves, hopes, peace, tranquility as well as mercies.

The concept of the family according to Islam is substantially no very different from the concept of thesakina family which is ruled in the Islamic law where the core aim of the family is to establish a household where the teaching of Islam is internalized in family values, mawaddahwarahmah. The main emphasis, however, is its implementation in regards to rights and obligations and the role of husband and wife in the household in details.

In the Islamic law, needs related to jasādiyahor physical needs or lahiriyahor bodilyneeds are well-articulated such as: clothing, food, housing, and social needs such as the need to interact with others.

\footnotetext{
${ }^{17}$ Ibid.
}

Moreover, needs related to rūhiyah or soul such as religious needs, needs of aqidah or needs of monotheism or faith are welltaken into account. There are also needs related to aqliyah or thinking or acquiring knowledge which in this case is called the need for education. ${ }^{18}$ All the needs mentioned above, the needs of Rühiyah or soul are the most important needs in human life. These needs are anything related to Islamic faith aqidahislamiyah. This matter is the most important part of our life because it will continue until the life hereafter. In addition to the needs fore-mentioned, there is a need obliged for every Muslim to be responsible for, i.e. enjoining good and forbidding evils which is in Islam wellknown as the task foramarma'rufnahimunkar.

\subsection{Marriage Conflict}

Family is the smallest social unit in society that plays a huge role in social and personaldevelopment of each family member. As the smallest unit in society, family needs its own organization and the head of the household needs to be an

\footnotetext{
${ }^{18}$ Ali Afandi, HukumWaris, HukumKeluargadanHukumPembuktian, (Jakarta: BinaAksara, 1986), 43.
} 
important figure who drives the family's life journey. ${ }^{19}$

Family members consist of father, mother and children. Family can be a strong unit if there is a good relationship between father-mother, father-child and motherchild. This good relationship is marked by a sense of harmony in their mutual relationship between all individuals withinfamily. Interpersonal interactions that occur in a family turn out to affect state of happiness (harmony) or unhappiness (disharmony) in one or several other family members.

A family is called harmonious when all family members feel happy, which is marked by having no tension and disappointment and satisfaction exists within all the circumstances. The existence of family members (existence or selfactualization) includes physical, mental, emotional and social aspects. Conversely, a family is called disharmony if there is one or several family members whose lives are filled up with conflict, tension, disappointment and are never satisfied and happy with their situation and existence.

This situation is related to failure or inability to adjust to others (partners) or to

${ }^{19}$ Sofyan S. Willis, Konselingkeluarga (Bandung: IKIP, 1995), 53. their social environment. Tension or conflict with a partner or between a husband and a wife is a natural thing in a family or household. No household runs without conflicts and therefore conflicts in the household is not anything to be frightened for.

If the conflict can be resolved in a healthy manner, each partner (husband and wife) will get a valuablelesson. Being aware and understand feelings, personality, lifestyle and emotional control of ones' partners can help family to reach happiness. A healthy conflict resolution occurs when each party, both husband and wife, does not prioritize personal interests. Instead,they seek the root of the problem and makes a mutually beneficial solution through calm and cool communication and togetherness. ${ }^{20}$

Family problems means that family life is chaotic, disorganized. Normally, in that situation parents lose authority to control the lives of their children, especially adolescents. Theyusually oppose parents and have constant quarrels between mothers and fathers, especially in regards to the matter of educating children. This type of problem in a family can lead to husband and wife divorce. In other words, family problem is a very unstable condition in a family where

\footnotetext{
${ }^{20} / \mathrm{bid}$.
} 
two-way communication in democratic conditions no longer exists. $^{21}$

If divorce occurs as the culmination of a prolonged problem, then children who suffer the most. Frequent cases of divorce in religious courts, the most complicated of all is who will take care of children. Very often the court wins custody of a man or father. In this case,religious courts are only based on mere legal facts.

\section{RESEARCH METHOD}

This research is a field study using a qualitative approach. The approach is an underlying assumption regarding the mindset of the subjects of the study. In writing this scientific work, the researcher uses qualitative descriptive approach in which aspects that are the objectives of the researchare empirically described. The approach seeks to find a better solution of the existing problems based on data. Thus, the researcher could ensure authenticity and accuracy of the data to be described. Descriptive research according to

${ }^{21}$ Darmadi, http://asihsinplasa.blogspot.com/2012/0 3/problem-yang-timbul-dalam-keluarga.html, Diakses, 6 Maret 2018.
SuharsimiArikunto "is more permanent when using qualitative approach". ${ }^{22}$

The setting of the study is the Office of the Religious Affairs (KUA), South Palusub-district, Palu, Central Sulawesi, Indonesia. The rationale behind the choice of the Office of the Religious Affairs (KUA) in South Palusub-districtwas based on the evidences that a number of marital conflicts occurred in this sub-district in recent years.

Data were collected using observation techniques, in-depth interviews and studies from shared written documents. The data analysis is undertaken implementing reduction and verification techniques to better understand data derived from various data sources. The data reduced and verified were then analyzed by claiming to the theoretical concepts used in this study.

\section{RESULTS AND DISCUSSION}

4.1 Efforts of the Office of the Religious Affairs in resolving marital conflicts

One of the duties of the Ministry of Religious Affairs at the time is to ensure the implementation of the Law number 22, 1946 concerning supervision and registration of marriage, divorce and reconciliation

\footnotetext{
${ }^{22}$ SuharsimiArikunto, ProsedurPenelitianilmiah, SuatuPendekatanPraktek, Ed. II, (Jakarta: RinekaCipta, 1993), 209.
} 
according to the Islamic law. The duty of the Ministry of Religious Affairs as stated in the law above is only to supervise and record the events of marriage, divorce, and reconciliation. It did not include how to maintain and care for and preserve marriages that have been carried out by the community.Consequently, it is up to each partner how to do that matter. In other words, the ministry of religious affairs (The Department of Religion) has no direct duty to look after and provide solutions to cases that occur in a family.

As an institution designed to provide services, the KUA has a very strategic role.Itfunctions and plays a strategic role in the community. Now frequency of services is getting wider and heavier, so it is not wrong to say that the KUA is a sub-districtlevel Ministry of Religious Affairs Office which becomes the oasis of all activities of the Ministry. In addition to carrying out marriage registration and marriage guidance, the KUA also undertakes assignments in the field of guidance / development of sakinah or love, peace, and hope families, halal or lawful products, partnerships, reckoning, mosques, zakat, endowments, social worship, BMT guidance, religious counseling, and guidance of pilgrims, not to mention the added reckoning of various issues that arise lately related to the Islamic religious matters such as the outbreak of the polemic of hidden marriages or siri, polygamy, early age marriages, and others.

In overcoming marital conflict, the Office of the Religious Affairs (KUA) in South Palusub-district based on the empirical data, researchers found that there were several efforts made, among others, is disseminating terms and conditions of marriage. One of the causes of marital conflict is marriage that has not reached the age of marriage. This was based on the interviewswith the head of the KUA of South Palusub-district as quoted in the following:

"One of the causes of many marital
conflicts is the early marriage or a
marriage that has not reached the age
of maturity. For that sake, in order to
preserve our household harmony in the
KUA, South Palusub-district, the
efforts are always made to disseminate
terms and conditions of marriage
according to the teaching of Islam and
the Islamic Law. This include
provisions regarding the minimum age
limit and the minimum requirement for
marriages in Indonesia is 16 years for
brides and 19 years for men."23

Other innovative steps taken by PetugasPencatatNikah - PPN(in charge officers appointed to record marriages) in

\footnotetext{
${ }^{23}$ TasdirRasada, "Wawancara", (Kantor KUA Kec. Palu Selatan) tanggal, 22 Mei 2018.
} 
minimizing marital conflict expressed byTasdirLasada as follows:

"The steps he took were to disseminate the marriage law No.1, 1974 to public through different types of events such as giving marriage advice and attending routine recitals held by a local Mosque official cleric board (Ta'mir). During the information dissemination, a marriage registrar also gives an explanation in public about adverse effects of marital conflict and the importance of maintaining harmony in the household. ${ }^{24}$

Geographical conditions and lack of human resources, are recognized as factors that cause the dissemination of the marriage law No.1 Year 1974 far slower than expected. However, this does not reduce enthusiasm of the KUA employees to continue their efforts to suppress marital conflicts that result in divorce.

One of the functions of the KUA is to carry out marriages and referral registration services. This is stated in the Decree of the Minister of the Religious Affairs No. 477, 2004 article 2 paragraph 2.The head of the church have the task for supervising and recording marriages and reconciliation. $\mathrm{He}$ or she is entitled to sign the book of marriage, register divorces, as well as give

\footnotetext{
${ }^{24}$ TasdirRasada, Kepala KUA, (Kantor KUA Kec. Palu Selatan) tanggal, 24 Mei 2018.
}

guidance and care services. The primary task of the Penghuluor the appointed person to conduct marriagein a marriage as mentioned in the decree of the Minister of Religious Affairs Number 477, 2004 article 7 , is to record marriage contract carried out in his area.In a marriage certificate according to the $\mathrm{N}$. marriage certificate model, it is signed by the Head of the KUA, husband, wife, wife's guardian and witnesses.After marriage contract has been completed and the marriage book is handed over to a married couple, the work of the Penghulu is done.

The role is considered as a measure that describes how to make a positive impact on the event. In this research,the achievement of the goals through various efforts as such reduced marital conflict in the are under the authority of the KUA South Palusub-district.

Marriage Registrar (PPN) is a formal leader whose leadership is based on a letter of decree stated in the Law number 22, 1974. His job includes looking after Marriage Registration, Divorce, and Referral. His position has been stipulated in the explanation of the Law number 22, 1946.

Meanwhile, based on the Minister of Religious Affairs Regulation number 11, 
2007 in regards to Marriage Registration, marriage registrar is held by the Head of the KUA who is responsible of checking requirements, supervisions, and recording marital / reconciliation events, registration of divorce, conducting marriage guidance and signing marriage certificates, referral act, marriage book (marriage certificate quote) and certificate of reference. In carrying out these duties, the head of the KUA is helped by an assistant.

The KUA office in its effort to carry out its role is not only bound to regulations of thegovernment, i.e. the Decree of the Minister of Religious Affairs of the Republic of Indonesia Number 517, 2001 article 3. However, in its practice the KUA office has various important agendas inencountering diversities, qualities of services, dynamic, and conducive society.

By giving this guidance and advice by the KUA (Penghulu), it is expected that each marriage conflict does not end with undesirable divorce. This was approved by the head of the KUA of South Palusubdistrict during the interview. Mr. TasdirLasada as the head of the KUA revealed as follows:

"Guidance for those who have been in conflict and live separately is helping them remember the time when they live harmoniously, foster good households, love one another, and take care of each other, and remain them what they have said in their marital oath when they first married. This is to remind them to continue their existing relationship to avoid divorce. 125

The role of the KUA in South Palu sub-district, apart from carrying out primary duties of the head of the office, is to develop planning for monitoring activities, supervision for the recording process and the implementation of marriage / referral services. Other duties of the head of the KUA are giving counseling and consultation of marriage / referrals, monitoring violations in marriage / referral provisions, munakahat(marry someone according to the Islamic Law), legal fatwa services and muamalah(social interaction)guidance, fostering sakinah(loving and peace) families, as well as monitoring and assessing knowledge development activities. Moreover, the head of the KUA is entitled to help his people develop their knowledge as well as act as a leading figure in dealing with religious issues in his society. These dual functions make the head of the KUA and his assistants must be more wellprepared and improve their knowledge and skills.

\footnotetext{
${ }^{25}$ TasdirRasada, Kepala KUA, "Wawancara", (Kantor KUA Kec. Palu Selatan) tanggal, 28 Mei 2018.
} 
There are a number of other efforts made by the KUA of South Palu subdistrictinits attempt to resolve marital conflicts including:

"We have to provide guidance to prospective brides who want to get married. We also need to give counseling in regard to the importance of marriage. The prospective brides must be strong physically and well-prepared mentally.The awareness of community in regards to legal age limit of marriage for men and women also needs to be continuously disseminated through various activities such as events in villages as well as in the Islamic activities. In these activities, we collaborate with religious leaders, and several related parties. " 26

Communities in the sub-district of South Palu have not fully support the implementation of the Marriage Law where many people still do and allow underage marriages due to various factors such as advances in technology and communication tools. In this context, teenagers can access anything provided in internet including while they are not able to choose what is good and not good for them.

To suppress such marital conflict in the South Palusub-district, the head of the KUA and his assistantdid various efforts.

${ }^{26}$ Lubis S Lanjupe,,Pegawai KUA, (Kantor KUA Kec. Palu Selatan) tanggal, 31 Mei 2018.
According to TasdirLasada, the head of the KUA in the sub-district, that:

"The method of giving advice to people who are married has been done at the time of marriage. Counseling, however, has been given at the stage of pre-marriage before ijabqabul (prenuptial agreement) contract. In the pre-wedding counseling, various parties including religious leaders, sub-district government and health center officials are involved.The involvement of the officials of health center is to ensure health condition of prospective bride and groom. ${ }^{127}$

TasdirLasada explained that the KUA of South Palusub-district hasseparate programs to reduce the occurrence of marital conflict in the community.

\subsection{Causes of Marriage Conflict}

In this life, problems are always there.The existing of problems in our lives are signs that we are still alive in this world. Likewise, in a marriage, there are various problems although its form and level of difficulties are not always the same. What needs to be highlighted is to know and recognize how to deal with the problems. There are several problems that occur very

\footnotetext{
${ }^{27}$ TasdirRasada, Kepala KUA, “Wawancara”, (Kantor KUA Kec. Palu Selatan) tanggal, 31 Mei 2018.
} 
often in each family as elaborated in the following way:

1) Earning / problem of income

The problem of living or incomeindeed cannot be underestimated. Many households are cracked in the early years of marriage because of having different opinions about living. There are many men who feel that family living is the obligation of both parties, both husband and wife. While a wife, even if she works, still hopes to be fully supported by her husband.

2) Poorly skilled wife in household affairs.

Another aspect that often becomes a problem is when a wife is not able to take care of the household. For example, a wife cannot cook properly, wash and iron clothes, clean and mop the house. In the end, these all things that potentially disappoints her husband or even in-laws.

3) Differences of views on many things. Naturally, different opinions are things thatmake the household more colorful. However, it becomes unnatural when these differences are exaggerated and foster hatred.

4) Communication problems are the most frequently encountered in the household 5) Excessive workloads.

Husband and wife who are equally busy usually have less time to communicate naturally. At most they just meet each other when they want to sleep, have breakfast or enjoy weekends. Lack of time for sharing and communicating often results in misinterpretation. Finally, when they meet instead of giving love to each other, they squabble.

6) Lack of attention

Sometimes feeling of tranquility in a household is disturbed by problems that arise from a husband or a wife. In many cases, paying attention a partner becomes serious necessities in a household. This condition requires serious attention and proper way of handling it in order for the household is under control.

7) Fighting each other

In building a happy household, it is certainly not as easy as we imagine. Fights often occur which it could be a trivial problem, exaggerated in such a way that a couple can nolonger control their emotions. The uncontrolled emotions can turn a discussion into a big argument that can leave deep scars for married couples as well as other family members.

8) Household Violence

When small or big problems occur in a household, it is often that a husband beats his wife with his hand. As such, the act of a 
husband could turn a household situation into danger which eventually causes divorce.

9) Child Problems

Usually, problems of children in regards to their education or the obligation to take care of children could also become a triggering point for a household conflict to happen. There are men who do not want to be bothered at all with the affairs of children. In fact, a wife can be very sensitive especially when she gives birth frequently. This could cause tension in the household if there is no immediate solution taken.

10). Large family interference

Either in-law, sister-in-law, or brotherin-law could potentially interfereone's household affairs. It will definitely create many problems between spouses. Therefore, it is important for couples to commit not to let large families interfere with any matter in a household to maintain good relationships between a husband and a wife.

\section{1). Physical problem}

Problems could also happen when a husband and a wife could no longer look after themselves in regards to their physical appearance. For example, when a wife turns fat and a husband's stomach gets bloated and they no longer look after their physical cleanliness, could be a cause of a household conflict. These physical appearance often become reasons for disharmony relations between a husband and a wife. Therefore, these problems cannot be underestimated. The Prophet (P.B.U.H.) even reminded that even a husband needs to maintain his physical agility as his wife takes care of her beauty to both respect and please each other. $^{28}$

Mr. TasdirLasadaexplained in an interview in July 2018, when families experience problems in their household, they should come to the office of the religious affairs (KUA) to get advice that might help solve the problem. Such advice could be very helpful in a household survival.

Based on document reviews and interviews in regards to marital conflict, it is evident that educational affairs are the most fundamental factors that causes a household conflict.

Education is a process carried out to develop and realize potentials of individualsin order for them to have selfcontrol, good personality, intelligence, noble character and skills needed in the community. Education is also a process of obtaining a better standard of living.For example, understanding potential negative

\footnotetext{
${ }^{28}$ Dokumen KUA KecamatanPalu Selatan, 2018
} 
effects of underage marriage enable a couple to better plan their family agendas for their lives to come. This issue is elaborated as the following interview:

"I was only a junior high school graduate as well as my wife.We then married sir. At that time, we decided to get married at the age of 21 years and my wife was 16 years old. We got married, sir.Apart from financial factors, education plays an important role.Rather than just being confused here and there, sir. We want to go to school but we can't. We are supported by our parents, sir, we were allowed to get married at the very young age,"29

The interview shows that couples who married at such underage marriages were due to poor formal education. Thus, they choose to marry at the underage to see their future. To them, this is the best way for their future life. The researchers further askedrelated to those problems as elaborated in this way:

"Yes, if a problem occurs, it comes naturally sir. I believe in every life of a person there must be a problem. Likewise, we in a family,we also often experience problems either small or middling problems. However, at all times we passed, thank God, all the problems that occurred can be resolved by discussion" 30

\footnotetext{
${ }^{29}$ Afandi, WargaKecPaluselatan, "Wawancara" (RumahWarga) tanggal, 28 Juni 2018.

${ }^{30}$ Ikmallksan, WargaKecPaluselatan, "Wawancara" (RumahWarga) tanggal, 28 Juni 2018.
}

The interview shows that the method of problem solving done by the informant is good enough. Having no rush to discuss the problem with parents will help them solve it effectively. This is consistent with the interviews conducted by the researchers with the head of the KUA related to the underage marriages. He made mention that:

"Yes, if it is related to the problems of the household, I do not know as a whole. It is because very few people report their problems directly to me even though we have prepared family counseling facilities for those who have household conflicts. Mostly because generally they are not ready to get married atthe young age. They have not had adequate knowledge in regards to marriage. Moreover, they have no or less income to support their family. However, since they are forced to marry at the underage marriage, they feel that which means burden for them "131

The interview shows that some people in South Palu sub-district did not obey the age limit for a marriage stated in the law. Moreover, they did not use facilities provided by the local KUA in solving their problems. This is in line with what the KUA employees said in the interviews that the impact of marriage at a young age causes many unexpected problems.

\footnotetext{
${ }^{31}$ TakdirLsada, Kepala KUA, "Wawancara" (Kantor KUA Kec. Palu Selatan) tanggal, 2 Juli 2018.
} 


\section{CONCLUSION}

The study shows that the existence of various efforts of the Office of the Religious Affairs or the KUA of South Palusubdistrict in solving marital conflicts in the sub-district brings a better social effect to the people around the sub-district.

In the socialization of the agendas related to the topic of the study, the KUA ofPalu Selatan sub-district gave clear explanations to the people about the adverse effects of marital conflict. The team of the KUA also highlights the importance of maintaining harmony in the household while stressing marriage counseling for couples to obtain better insight about maintaining the household. This provision is delivered through pre-marital guidance programs or courses for prospective brides and families in the local area. The office provides guidance on how rights and obligations of a husband and a wife, their responsibilities as parents for their children in the future, management of problems and household conflicts, as well as how to manage their families so they can achieve the life they aspire to.

The study shows that supporting factors are adequate facilities and infrastructure, collaboration with other agencies, legislation that provides legitimacy services based on the KUA function according to the Decree of the Minister of the Religious Affairs - No 517 2001concerning the organizational structuring of sub-district religious affairs office article 2 and 3.The availability of the legislation supports the implementation of the KUA programs and activities.

The study also shows thatleadership commitment as a determining factor in achieving the goals set up by the KUA in the form of accelerating the commitment of the head of the KUA, Penghulu (in charge person for marrying others), and staff within the KUA of South Palu sub-district, the role of religious leaders in the community, indeed have indirectly assisted the local KUA officials in minimizing marital conflicts in the sub-district. Meanwhile,the study shows that the inhibiting factors which potentially hamper the KUA programs to resolve marital conflicts in the sub-district are the incomplete pre-marital and postmarriage guidance material, the lack of discipline among participants, andthe limited time allotments to disseminate the programs. Moreover, it is found that the distance between the bride and groom's residence or distant marriage partner and the lack of community awareness about the 
importance of BP4 are triggering factors that could potentially cause marital conflicts in the area.

\section{BIBLIOGRAPHIES}

Al-'Asqallani, Al-Hafiz Ahmad bin 'Ali bin Hajar . Fath al-Bariy bi Syarh Sahih al-Bukhari, Juz 11 (Cet. 1). Riyad : Dar Tibah, 1426 H/2005 M

Abî Al-Husain Muslim Ibnu Al-Hajjâj. Shahîh Muslim, Juz 9. Beirut: Dâr alKutûb al-'Ilmiah, t.th.

Abdul Baqi, Muhammad Fuad. Tafsir Tematis, Jilid 2. Surabaya: Halim Jaya, 2012.

Abdul Qadir, Muhammad. Probelamatika Keluarga. Bandung: PT Aditya Bakti, 2012.

Abdullah.

Faktor-faktor yang mempengaruhi strategi perempuan bekerja dan kesejahteraan keluarga. Jakarta: SinarGrafika, 1995.

Abdurahman. karakteristik lelaki shälih. Bandung: Gema Press, 2011.

AbidinSlamet, Aminuddin. Fiqih Munakahat I. Bandung: Pustaka Setia, 1999.

Achdiat. komunikasi keluarga. Jakarta: Elka, 2014

Afandi, Ali. Hukum Waris, Hukum Keluarga dan Hukum Pembuktian. Jakarta: BinaAksara, 1986.

Ahmad Syaebani, Beni. Perkawinandalam Hukum Islam dan Undang- Undang (Perspektif Fiqih Munakahatdan UU No 1/1974 tentang poligami dan Problematikanya.

Bandung: PustakaSetia, 2008.

Ahmadi, Abu. Psikologi Sosial. Jakarta: Rineka Cipta: 2002.

Arikunto, Suharsimi. Prosedur Penelitian Ilmiah, Suatu Pendekatan Praktek, Ed. II. Jakarta: RinekaCipta, 1993.
Assead, Abd al-Muhaimin. Risalah Nikah Penuntun Perkawinan. Surabaya: Bulan Terang, 1993.

Ash-Shiddieqy, Teungku Muhammad Hasbi. $\begin{array}{crr}\text { Al-Islam } & \text { Kepercayaan } & \text { Kesusilaan } \\ \text { Awal } & \text { Kebajikan. } & \text { Jakarta: }\end{array}$ BulanBintang, 1969.

Azkiya,Nabila.https://.blogspot.com/2016/0 3/psikologi-keluarga-teorikonflik.html, Diakses 29 Agustus 2018.

Bakry, Nazar. Problematika Pelaksanaan Fiqh Islam. Jakarta: PT. Raja Grafindo Persada, 1994.

Dahlan, Dkk. Ensiklope di Hukum Islam. Jakarta: PT IchtiarBaru van Hoeve, 1996.

Darmadi. http://asihsinplasa blogspot com/2012/03/problem-yangtimbuldalam keluarga.html, Diakses, 6 Maret 2018

Departemen Agama RI. IlmuFiqh, Jilid II. Jakarta: Gema, 1985.

$\begin{array}{cr}\text { Tafsirnya } & \text { (Edisi } \text { Qur'andan } \\ ----1 \text { yang }\end{array}$ Disempurnakan) jilid X. Jakarta: Departemen Agama RI, 2010

Departemen Pendidikan Nasional. Kamus Besar Bahasa Indonesia. Jakarta: Balai Pustaka, 2007.

Djubaidah, Neng. Pencatatan Perkawinandan Perkawinan Tidak Dicatat. Jakarta: SinarGrafika, 2010.

Durbin. Aplikasi Kepemimpinan Dalam Institusi. Bandung: Yaya Press, 2005.

Dyah, Ratna Meta. dalam, http://metakerenz.blogspot.co.id/2009/ 12/http://metakerenz.

blogspot.co.id/2009/12/ perananibu dalam keluarga, Diakses 6 Maret 2018.

Edwin. Kepemimpinan Transformatif. Bandung, Risalah, 2007.

Elmawati. Managerial skills. Jakarta: Prenada Media, 2007. 
Hakim, Rahmat. Hukum Pernikahan Islam. Bandung: PustakaSetia, 2000.

Hasan, M. Ali. PedomanBerumah Tangga dalam Islam. Jakarta: Siraja, 2006.

Hasby Ash Ahiddieqy, Teungku Muhammad. Al Bayan, TafsirPenjelas Al- Qur'anul Karim. Semarang: PT. PustakaRizki Putra, 2002.

Helmawati. pendidikan keluarga(Jakarta: Prenada Media, 2010.

Hertina. Sosiologi keluarga. Pekanbaru: Alaf Riau, 2009.

Ibrahim, Husen. Fiqh Perbandingan dalam Masalah Nikah, Talakdan Rujuk. Jakarta: IhyaUlumudin, 1971.

Ichsan, Achmad. Hukum Perkawinan Bagi Yang Beragama Islam. Jakarta: CV. Muliasari, 1986.

IdrisRamulyo, Mohammad. Hukum Perkawinan Islam. Jakarta: Bumi Aksara, 1996.

James K. Van Fleet, Leadership Management: Manajemen Kepemimpinan. Terj. Ahmad Susanto. Jakarta: Mitra Usaha, 2006.

Kisyi, Abdul Hamid. Bimbingan Islam untuk Mencapai Keluarga Sakinah. Bandung : Al- Bayan. 1995

Khoiriyah. Reorentasi Peranan Keluarga dalam Islam. Yogyakarta: Teras, 2012. Kompilasi Hukum Islam pasal 17

Al-maraghiy,AhmadMusthofaTafsir al maraghiy (Jilid 5),Terj. K Anshori Umar. Semarang, Toha Putra, 1988.

M, Fauzan. Pokok- pokok Hukum Islam. Jakarta: PT. Raja Grafindo Persada, 2002.

Mardani. Hukum Perkawinan Islam di Dunia Islam Modern. Yogyakarta: GrahaIlmu, 2011.

Milles, Matthew B. et.al. Qualitative Data Analisys, Terj. Tjetjep Rohen di Rohidi, Analisis Data Kualitatif, buku Sumbertentang Metode-metode Baru. Jakarta: UI-Press, 1992.
Moleong, Lexy J. Metodologi Penelitian Kualitatif. Bandung :Remaja Rosdakarya, 2002.

Muchtar, Kamal. Asas-asas Hukum Islamtentang Perkawinan. Jakarta: Bulan Bintang, 1993.

Munir, Amin, Peranan Keluarga Dalam Rumah Tangga. Jakarta: Amzah, 2010.

Myron, Weiner. Modernisasi Dinamika Pertumbuhan. Yogyakarta: Gadjah Mada University Press, 2008.

Narbuko, Choliddan Ahmadi Abu. Metodologi Penelitian. Jakarta: Bumi Aksara, 2000.

Nasution, S. Metode Research Penelitian Ilmiah. Jakarta :Bumi Aksara, 2004.

Peraturan Pemerintah Nomor 9 Tahun 1975 tentang Pelaksanaan Undang- undang Nomor 1 Tahun 1974 tentang Perkawinan.

PMA Nomor 11 Tahun 2007 pasal 1 (1)

Puspitawati. Konsep dan teori keluarga. Bogor: Departemen Ilmu Keluargadan Konsumen Fakultas Ekologi Manusia- Institut Pertanian, 2013

Prodjodikoro, Wirjono. HukumPerkawinan Indonesia. Bandung: Sumur, 1974.

Al-Qurthubi, Muhammad. Al-Jami' li Ahkam Al-Quran Juz XVIII. Beirut: Dar-al- Ihya li Tirkah al-Arabi, 1985.

QadirJawas. Yazid bin Abdul. Paduan keeluarg sakinah. Bandung: Pustaka Imam syafi'I, 2009

Rofiq, Ahmad. HukumIslam di Indonesia. Jakarta : PT. GrafindoPersada, Persada, 2000.

Rusyd, Ibnu. Bidayah al-Mujtahid: AnalisaFiqih Para MujtahidTerj. M.A. Abdurrahman. Semarang: Asy-Syifa', 1990.

Al-Shabuni, Muhammad Ali. TafsirAyat AlAhkam min Al-Qur'an Al-Karim. Beirut: Dar IbnAbbud, 2004), 131. Liha tJuga Maktabah Syamila 6888, Tafsir Ayat Al-Ahkam, t.t. 
Sedarmayanti. Manajemen sumberdaya manusia reformasi birokrasi dan manajemen pegawai negerisipil. Bandung: PT. RefikaAditama, 2014 Shihab, Qurais. Kepemimpinan dalam keluarga. Jakarta: BumiAksara, 2000.

-------------. Tafsir Al Misbah: Pesan, Kesan Dan Keserasian Al Qur'an. Jakarta: LenteraHati, 2003), 185.

Singarimbun, Masri. MetodePenelitianSurvai. Jakarta: PT Pustaka LP3S Indonesia. IKAPI, 1995.

Strauss A.Murray. $\quad$ https://blessedday4us wordpress com/2010/06/02/problemat ika dalam- keluarga/,Diakses, 6 Maret 2018

Sudarsono. HukumPerkawinanNasional. Jakarta: RinekaCipta. 1997.

Sudarsono. Pokok-pokok Hukum Islam. Jakarta: RinekaCipta, 1992.

Sugiyono. Metode Penelitian Kuantitaif, Kualitatifdan $R \& D$. Jakarta: Alfabeta, 2011.

Suharna,Nana. Probelamatika dalam Keluarga. Bandung:PT. Al-Ma'arif, 1986.

Suharyanto. Pemimpin Masa Depan. Semarang, Alkaff, 2002.

Supriyadi, Dedi. Bunga Rampai Sosiologi Keluarga. Bandung: Pustaka Setia, 2008.

Surakhmad, Winarno. DasardanTeknik Research

PengantarMetodologillmiah, Ed.VI.

Bandung, Gema Press, 1978.

Syarifuddin, Amir. Hukum Perkawinan Islam di Indonesia: Antara Fiqh Munakahat dan Undang-undang Perkawinan. Jakarta: Kencana Prenada Media Group, 2006.

S, Lestari. Psikologi keluarga: Penanaman nilai dan penanganan konflik dalam keluarga. Jakarta: Kencana Prenada Media Group, 2012
Tama, Rusli. Perkawinanantar agama danmasalahnya. Bandung: Shantika Dharma, 1984.

Tiar, Azis $\mathrm{k}$. https://.wordpress.com/2014/05/07/pe ngaruh-masalah-ekonomi- dalamkeutuhan-keluarga/, Diakses, 6 Maret 2018

Undang-UndangTahun tentangPerkawinan

Undang-Undang No. 23 Tahun 2004 Tentang Tindak Kekerasan Terhadap Istri Dalam Rumah Tangga

Wardana, A. Teorikonflik 2: non marxis. Handout kuliah. Diaksesdari https://www.google.com/url? sa=t\&r $c t=j \& q=\&$ esrc $=s \&$ source $=$ web $\& c d=$ $3 \& c a d=r j a \&$ uact $=8 \&$, Diakses 29 Agustus 2018.

WarsonMunawir, Ahmad. Kamus Al Munawwir. Yogyakarta: Gema Press, 1984.

Willis, Sofyan S. Konselingkeluarga. Bandung: IKIP, 1995.

Yunus, Mahmud. Tafsir Quran Karim, Cet. VII. Jakarta: PT. HidakaryaAgung, 2004.

Zahro, Azizah. https: 96.wordpress com /2014/05/02/makalahprobem- i-dalamkeluarga-konseling-keluarga/,

Diakses, 6 Maret 2018 